\title{
OXYGEN SENSING IN THE KIDNEY AND ITS RELATION TO ERYTHROPOIETIN PRODUCTION
}

\section{Bauer and A. Kurtz}

Physiologisches Institut der Universität Zürich, Winterthurerstrasse 190, 8057 Zürich, Switzerland

\section{INTRODUCTION}

More than 30 years ago the kidney in adult mammals was found to be an essential component of a regulatory feedback loop that controls the number of red blood cclls and thereby the oxygen capacity of the blood. The kidncy releases a hormone, erythropoietin, that stimulates erythrocyte formation in the bone marrow (26). The rate of release of erythropoietin from the kidney is greatly enhanced by various forms of hypoxia, such as hypoxic hypoxia, anemia, and carbon monoxide poisoning (27). The question that arises, therefore, is whether the oxygen sensor that controls the production of erythropoietin resides outside or inside the kidney. Results of experiments obtained on animals without functioning arterial chemoreceptors as well as with artificially perfused kidneys or renal hypoperfusion point toward an intrarenal localization of the oxygen sensor $(9,27,50)$. In this context, the renal oxygen sensor is operationally defined as a receptor mechanism that controls the production of erythropoietin.

This overview aims to conceptualize present knowledge on the physiological parameters relevant for the transduction mechanism in the kidney through which the synthesis of erythropoietin might be stimulated. More specifically we discuss $(a)$ the type of oxygen signal that regulates erythropoietin production, $(b)$ the location of the oxygen sensor within the kidney, and $(c)$ the transduction mechanism that generates effector molecules that might stimulate the synthesis of erythropoietin. 


\section{WHAT KIND OF OXYGEN SIGNAL IS PERCEIVED BY THE RENAL OXYGEN SENSOR?}

\section{Oxygen Supply to the Normoxic Kidney}

THE DISTRIBUTION OF OXYGEN IN THE NORMAL KIDNEY IS NOT HOMOGENEOUS Normally the kidney receives a relatively large share of the cardiac output (about 20-25\%), which is necessary for filtration and excretion of waste products. Consequently, the volume of oxygen transported to the kidney is large compared with the overall oxygen consumption; only 8-10\% of the oxygen delivered to the kidney is actually used. Nonetheless, the kidney is remarkably susceptible to hypoperfusion; acute renal failure is a frequent complication of hypotension caused by hypovolemia or shock and significantly outnumbers the incidence of brain, liver, or heart failure in the same clinical condition $(11,54)$.

Such a disproportion between oxygen delivery and susceptibility toward hypoperfusion can be reconciled by gradients of oxygen availability within the renal parenchyma. In 1960 Aukland \& Krog (2) demonstrated in exposed kidneys of anesthetized dogs that the renal cortex $\mathrm{pO}_{2}$ and the urine $\mathrm{pO}_{2}$ are much lower than the venous blood $\mathrm{pO}_{2}$. Furthermore, clamping of the renal artery or induction of anemia lowered $\mathrm{pO}_{2}$ in the cortex and outer medulla but not the inner medulla $(1,2)$. These results are in keeping with the demonstration of Baumgärtl and co-workers that large variations in respired oxygen concentration mostly affect cortical $\mathrm{pO}_{2}(6)$. These authors also found that $85 \%$ of the $\mathrm{pO}_{2}$ frequency distribution in the dog renal cortex is below the $\mathrm{pO}_{2}$ in the renal vein. The critical $\mathrm{pO}_{2}$, i.e. the $\mathrm{pO}_{2}$ below which oxygen consumption falls, is also quite high: 35 torr in the venous effluent of the isolated perfused kidney (17), as compared with the critical $\mathrm{pO}_{2}$ in renal cortical tissue of approximately 10 torr (40). These results are best explained by oxygen shunting that drains oxygen from the arterial to the venous segment of the capillaries, not only in the medulla but also in the renal cortex $(6,11,40,41$, 53). Note that the peritubular capillary plexus in the renal cortex possesses a hairpinlike configuration. Thus, the glomerular capillaries, efferent arterioles, and their initial peritubular capillary subdivisions pass through, and are intimately surrounded by, capillaries with a lower $\mathrm{pO}_{2}(32,57)$. This anatomical arrangement allows for diffusion of oxygen from arterial to venous blood and is equivalent to postglomerular shunting. In addition, significant preglomerular shunting apparently exists from the intralobular artery to the intralobular vein. This type of oxygen shunt lowers the $\mathrm{pO}_{2}$ in the superficial glomeruli of the Munich Wistar rat to $\mathrm{pO}_{2}$ values between 40 and 50 torr (53). In summary, the evidence suggests there are considerable inhomogeneities of oxygen supply within the kidney cortex, despite the fact that the kidney is supplied with large amounts of oxygen. 


\section{Renal Function During Hypoxia}

THE OXYGEN CONSUMPTION OF THE KIDNEY IS NOT GREATLY ALTERED UNDER HYPOXIC CONDITIONS From the large body of data on the reactions of body fluid volumes and renal function in high-altitude hypoxia or anemia, the following picture emerges: Under conditions of moderate hypoxia (arterial $\mathrm{pO}_{2}>35$ torr in hypoxic hypoxia; hematocrit approximately $20 \%$ in anemic hypoxia), renal blood flow and glomerular filtration rate do not change significantly [reviewed in (23)]. This evidence can be explained partly by the observation that the renal blood flow does not increase in proportion to the rise in cardiac output that occurs in hypoxia (22). Only in conditions of severe hypoxia have some investigators observed a relative decrease in the glomerular filtration rate in comparison with renal blood flow, which leads to a decrease in filtration fraction $(1,56,63)$. Furthermore, the initial hemoconcentration observed under conditions of acute arterial hypoxia is apparently caused by an increase of renal sodium and water excretion. This hypoxia-induced natriuresis is, however, most likely controlled by extrarenal factors $(7,23,24,39)$ and cannot be explained by a direct inhibition of tubular reabsorptive function caused by a shortage of oxygen. The fact that at moderate degrees of hypoxia the filtration fraction remains more or less constant is important, because it indicates that the workload of the kidney stays constant. The workload of the kidney is determined by the amount of sodium that must be reabsorbed per unit time. Because the sodium reabsorption largely governs the oxygen consumption of the kidney $(16,30,38,60)$, the global oxygen consumption of the kidney would not be expected to change significantly under hypoxic conditions, and this result is observed experimentally (60). Even under conditions in which the filtration fraction is decreased, the oxygen consumption of the kidney remains unaltered; this phenomenon appears to be related to more efficient oxygen extraction from the blood by an increase in the $\mathrm{pO}_{2}$ gradients between the peritubular capillaries and the oxygen-consuming cells (1).

\section{The Information Coding of the Renal Oxygen Sensor}

THE RENAL OXYGEN SENSOR DETECTS CHANGES IN VENOUS $\mathrm{PO}_{2}$ An exponential relationship between the plasma levels of erythropoietin and the degree of hypoxia has been well established (19). Before considering the oxygen signal that controls erythropoietin formation, we offer a brief background on erythropoietin, highlighting the newest developments in this field. In 1977 Miyake, Kung, \& Goldwasser (46) described the purification of the hormone from the urine of anemic patients. Since then, the gene coding for human erythropoietin has been cloned and the amino acid deduced from the gene structure (45). Erythropoietin is a glycoprotein with a mass of approximately 34,000 daltons, of which some $40 \%$ is represented by the carbo- 
hydrate part. The protein part consists of 166 amino acids with both O-linked and $N$-linked saccharides, which are the anchor for the complex carbohydrate structure (52). cDNA clones for human erythropoietin have been isolated, and the expression of erythropoietin cDNA clones has been achieved $(25,42,51)$. Furthermore, the advent of molecular probes has yielded evidence that hypoxia leads to an accumulation of erythropoietin mRNA in the kidney, which regulates erythropoietin production $(8,10,55)$.

We define the sensitivity of the oxygen renal sensor that controls erythropoietin production by the amount of hormone produced at a given degree of hypoxia. Under steady state conditions, the serum level of erythropoietin is proportional to the production rate because there is no indication of direct, oxygen-dependent regulation of erythropoietin degradation. Furthermore, the sensitivity of the oxygen sensor presumably depends upon the ratio of oxygen supply to the kidney and oxygen consumption of the kidney. An increase in the oxygen transport capacity should therefore lead to a decrease in the stimulus to the oxygen sensor and thereby to a reduced erythropoietin response. We have tested this hypothesis by exposing mice with different hematocrit values to an atmosphere containing either $8 \% \mathrm{O}_{2}$ or $0.1 \% \mathrm{CO}$ in air. Figure 1 shows that there is an inverse relationship between erythropoietin response and oxygen transport capacity of the blood. These results indicate that $(a)$ the renal oxygen sensor records changes in the ratio of oxygen supply to oxygen demand and $(b)$ it is sensitive to the venous $\mathrm{pO}_{2}$ because this variable changes when the oxygen transport capacity of the blood increases or decreases.
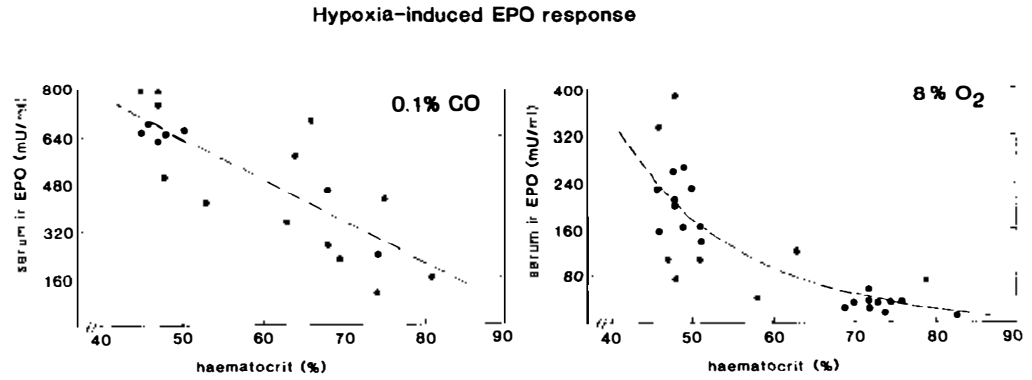

Figure 1 The relationship between hematocrit and hypoxia-induced erythropoietin (EPO) response. Mice were rendered polycythemic during a 15-day period of intermittent (20-22 h/day) normobaric hypoxic hypoxia $\left(7-8 \% \mathrm{O}_{2}\right)$. Four and 12 days later, polycythemic animals together with normocythemic controls were exposed to either hypoxic hypoxia $\left(8 \% \mathrm{O}_{2}\right)($ right $)$ or carbon monoxide $(0.1 \% \mathrm{CO})$ (left) for $3 \mathrm{hs}$. The EPO-response induced by this hypoxic stress is plotted against the hematocrit values of the animals [taken from Ref. 32a with the permission of Karger (Basel)]. 


\section{THE LOCATION OF THE RENAL OXYGEN SENSOR}

\section{Erythropoietin Production and the Oxygen Sensor Are Located in the Renal Cortex}

The next question regards the location of the renal oxygen sensor that is involved in the elaboration of erythropoietin. Assuming the sensor is sensitive to oxygen supply and tubular oxygen consumption, one expects a decrease in the sensitivity of the oxygen sensor when tubular oxygen consumption is reduced by interference of transport rates. By using site-specific transport inhibitors, researchers should be able to localize those tubular structures that are associated with the hypoxia-dependent erythropoietin formation. We have used acetazolamide (proximal tubule), furosemide (loop of Henle), hydrochlorothiazide (early distal tubule), and acetazolamide (late distal tubule) in mice and produced in every case a highly significant natriuresis, which is indicative of a reduced tubular sodium reabsorption. Only when the proximal tubular sodium reabsorption was inhibited by approximately $30 \%$, however, was the hypoxia-induced erythropoietin response elicited by $8 \% \mathrm{O}_{2}$ or $0.1 \%$ carbon monoxide significantly reduced (K.-U. Eckardt, A. Kurtz, C. Bauer, unpublished results). From the data shown in Figure 1 and the results obtained with the site-specific transport inhibitors, we conclude that the $\mathrm{pO}_{2}$ in the peritubular capillaries of the convoluted and straight proximal tubule is the essential variable involved in the regulation of erythropietin production. This idea agrees with two recent reports in which cells containing erythropoietin mRNA were localized in the kidney cortex by using in situ hybridization $(31,37)$. The mRNA encoding the erythropoietin was detected mainly in the kidney cortex in the peritubular interstitium in close proximity to the basolateral membrane of the cortical tubules. The two groups of authors suggest that the endothelial cells of the peritubular capillaries are the ones that produce erythropoietin.

From a physiological point of view, this location is sensible because the cells are physically positioned to measure the ratio of oxygen supply (from the capillary lumen) to oxygen consumption (from the basolateral membrane of the tubuli). Further experiments are necessary, however, to prove that the cells that produce erythropoietin are of endothelial origin. Remember that endothelial cells also release prostacyclin under hypoxic conditions (12). This derivative of arachidonic acid mctabolism stimulates erythropoietin production in cultures of renal cells (33). Therefore, locally produced prostacyclin could, in an autocrine fashion, stimulate erythropoietin formation in the erythropoietin-producing cells. 


\section{THE TRANSDUCTION MECHANISM OF THE RENAL OXYGEN SENSOR}

\section{The Biochemistry of Oxygen Sensing}

ATP COULD BE AN EFFECTOR MOLECULE IN OXYGEN-DEPENDENT BIOLOGICAL REACTIONS The fact that the oxygen dependence of mitochondrial oxidative phosphorylation extends well into the physiological range, i.e. up to $\mathrm{pO}_{2}$ values of 60 torr $(18,29)$, is critical to the understanding of oxygendependent physiological reactions. It allows mitochondria to function as tissue oxygen sensors by converting information on intracellular $\mathrm{pO}_{2}$ values into a metabolic signal, which is reprcsented by $[\mathrm{ATP}] /[\mathrm{ADP}]\left[\mathrm{P}_{\mathrm{i}}\right](64,65)$. Therefore, in terms of receptor physiology, the mitochondria themselves would act as oxygen sensors by converting the signal "hypoxia" into a change of cytosolic $[\mathrm{ATP}] /[\mathrm{ADP}]\left[\mathrm{P}_{\mathrm{i}}\right]$, which can be regarded as effector molecules in this transduction mechanism.

Recall that $[\mathrm{ATP}] /[\mathrm{ADP}]\left[\mathrm{P}_{\mathrm{i}}\right]$ not only governs electron flow and oxidative phosphorylation in the mitochondria but that individual components of this three-membered family are important links among the activities of glycolysis, the citric acid cycle, and oxidative phosphorylation. Apart from these more general interactions, ATP at physiological concentrations can control a number of cellular variables such as a voltage-independent $\mathrm{K}^{+}$conductivity in cardiac muscle (48) and pancreatic B cells (15). Furthermore, a reduced availability of ATP to the enzyme phosphatidylinositol-4-phosphate kinase (43) appears to lead to a decrease in the contractility of smooth muscle under hypoxic conditions (14).

In the kidney, a tight coupling is observed between oxidative metabolism and the $\mathrm{Na}, \mathrm{K}$-ATPase activity, which thereby accounts for the tight coupling between $\mathrm{Na}^{+}$transport and oxidative metabolism $(44,58)$. Results from several experiments have led to the hypothesis that there are microheterogeneities within cells with regard to the delivery of ATP from mitochondrial oxidative phosphorylation to the Na,K-ATPase $(3,59)$ located at the basolateral side of kidney epithelial cells in association with the cytoskeletal protein ankyrin (47). Furthermore, that the proximal tubule has quite a low capacity to maintain [ATP] via glycolytic sources is interesting (4). A decrease in oxygen supply to the proximal tubules with a subsequent fall of $[\mathrm{ATP}] /[\mathrm{ADP}]\left[\mathrm{P}_{\mathrm{i}}\right]$ is therefore a more direct indicator of a hypoxic condition in the proximal tubules compared with the more distal parts of the nephron, which have a much higher glycolytic reserve $(4,13)$. In addition, a hierarchy exists in the maintenance of energy-dependent processes in the proximal tubule such that ATP used for transport can bc "borrowed" from other ATP-dependent processes in conditions of reduced oxidative phosphorylation (59). Such a preferential delivery of ATP to the $\mathrm{Na}, \mathrm{K}$ - 
ATPase under conditions of reduced ATP availability would lead to local imbalances of the ATP distribution at the cytosolic side of the plasma membrane and ATP-dependent regulatory mechanisms could be set in motion.

\section{The ATP Dependency of Prostaglandin Formation}

PROSTAGLANDINS SEEM TO BE INVOLVED IN THE ELABORATION OF ERYTHROPOIETIN How can the results described above be translated into an oxygen sensor that governs erythropoietin production? We can provide only a conceptual framework, which arises from the following observations: (a) A functioning prostaglandin system is necessary for the elaboration of hypoxiainduced crythropoietin production [reviewed in $(20,27)]$. (b) Under hypoxic conditions, the renal excretion of prostaglandins increases (61). (c) Addition of arachidonic acid and prostaglandins of the E type to the perfusion fluid increases the release of erythropoietin in artificially perfused kidneys [reviewed in 20,27)]. (d) Stimulation of $\mathrm{NaCl}$ transport in layers of a highresistance renal epithelial cell line led to a stimulation of oxygen consumption and release of prostaglandin $E_{2}$ from the basolateral side of the cells $(34,35)$. $(e)$ The same increase in prostaglandin $\mathrm{E}_{2}$ release can be achived by treating these cells with the uncouplers of oxidative phosphorylation, amobarbital and rotenone (35). The entirety of these results led to the proposal that the hypoxia-induced release of prostaglandin $E_{2}$ is due to a local fall of ATP at the basolateral side of the membrane of these cells. The enzyme that would be inhibited by a shift of ATP to the Na,K-ATPase is acyl-Co-A-synthetase, which has a high $\mathrm{Km}$ for ATP of approximately $4.5 \mathrm{mM}$. Inhibition of this enzyme results in the inhibition of reesterification of arachidonic acid, the rate-limiting substrate for prostaglandin synthesis $(5,35,62)$.

Whilst such a scheme, in which hypoxia leads to production of prostaglandin $E_{2}$ by a local decrease in ATP, can explain some aspects of the hypoxiainduced and prostaglandin-mediated elaboration of erythropoietin, problems remain as to the nature of the oxygen-sensing mechanism. The first is the way by which prostaglandins enhance the transcription rate of the gene coding for erythropoietin under conditions of hypoxia. Some investigators suggest that prostaglandin $E_{2}$ stimulates adenylate cyclase and that the erythropoietin gene would therefore belong to those genes whose promoter is regulated by cAMPdependent protein kinases [reviewed in $(20,27)]$. The evidence on which this hypothesis rests is circumstantial, however, and more direct experiments necd to be done before the cAMP-dependency of the erythropoietin gene can be accepted.

Second, as Jones (28) has indicated, many oxygen-dependent biochemical reactions are found in the kidney. All of these oxygen-dependent reactions would not easily explain the fact that erythropoietin is continuously produced 
by normoxic kidneys. Perhaps the low but constant production of prostaglandins in the normal kidney (62) is sufficient to maintain normal day-to-day erythropoietin production. The mere fact, however, that normal erythropoietin production is so delicately regulated renders unlikely the possibility that the normal production rate depends on a single effector system such as the prostaglandins.

Another metabolic indicator of renal hypoxia or renal metabolic rate is adenosine [reviewed in (49)]. The enzyme that dephosphorylates AMP to adenosine, ecto-5'-nucleotidase, is found in distinct regions of the kidney cortex. Enzyme activity is present in the brush border of the proximal tubule, highest in the $P_{1}$ segments with decreasing intensity in the $P_{2}$ and $P_{3}$ segments and also in the peritubular and perivascular fibroblasts of the cortical labyrinth (B. Kaissling, personal communication). In two recent reports it was shown that administration of adenosine leads to an increase of erythropoietin formation in mice (60a) and in insolated perfused kidneys (49a), possibly by binding to a cell surface receptor of the $\mathrm{A}_{2}$-subclass. Adenosine is known, however, to cause a transient fall in renal blood flow (49) and a persistent reduction in glomerular filtration rate (22a). It is not clear, therefore, if adenosine enhances erythropoietin formation by an intrarenal decrease in blood flow or by a direct effect on the hormone-producing cells.

\section{SUMMARY AND PERSPECTIVES}

Under normal circumstances there is a constant relationship between global renal blood flow and global renal oxygen consumption that is reflected by the linear dependency of oxygen consumption upon sodium reabsorption $(16,30$, $38,60)$. Due to the marked heterogeneity of tissue $\mathrm{pO}_{2}$ within the kidney, however, a reduction of oxygen delivery to the kidney leads to even more pronounced changes of local tissue $\mathrm{pO}_{2}$, almost exclusively in the kidney cortex and the outer region of the medulla $(11,53,54)$. We summarize the possible function of the renal oxygen sensor that controls erythropoietin formation with the aid of Figure 2.

Two possibilities are considered: First, the oxygen sensor is localized within the erythropoietin (EPO)-producing cell, perhaps specialized endothelial cells $(31,37)$ in the peritubular capillaries of the proximal tubule. One of the biochemical messengers in such a case could be prostacyclin, which is released from endothelial cells under certain conditions of hypoxia (12) and stimulates erythropoietin formation in cultures of renal cells (33). In this scheme, the role of the tubular cell would be that of an oxygen sink that merely soaks away oxygen and thereby records changes in oxygen supply. The second possibility is that the proximal tubule generates a biochemical signal that acts on the erythropoietin-producing cell. Such a signal could be 


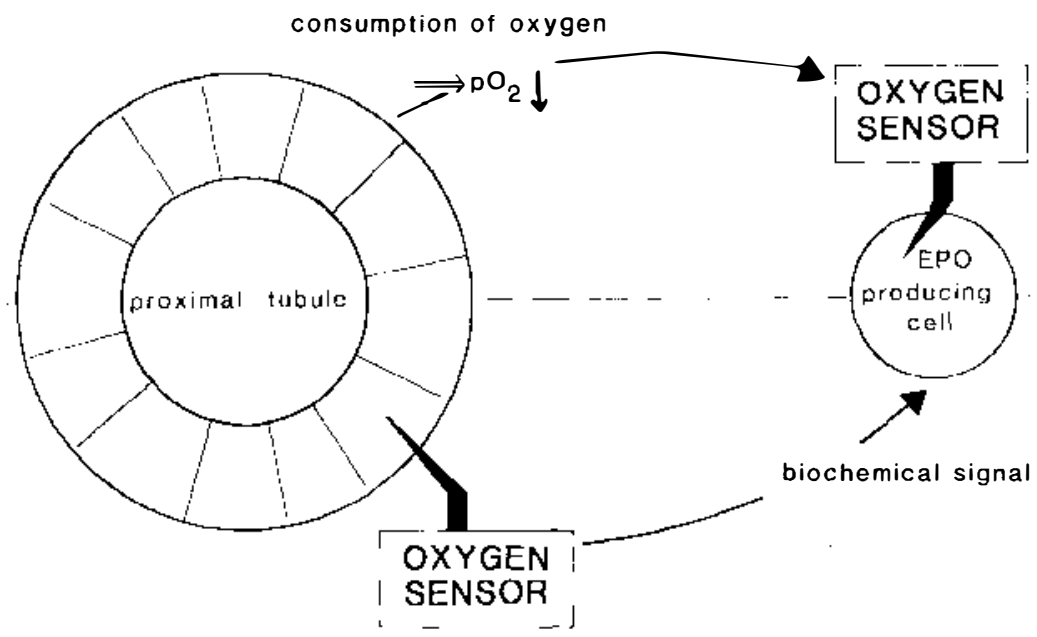

Figure 2 Schema for two possible mechanisms of the renal oxygen sensor. Right: The oxygen sensor is located in the erythropoietin (EPO) producing cell and responds to oxygen taken away from the proximal tubule. Left: The sensor is located in the tubular wall and conveys information to the EPO producing cell by chemical messengers.

prostaglandin $E_{2}$, which is released from the basolateral side of renal epithelial cells when there is a mismatch between oxygen supply and oxygen consumption (35). Other biochemical signals such as ATP or adenosine (21, 49) can also be considered candidates in this transduction mechanism. Nucleotides such as ATP or ADP stimulate prostacyclin release from endothelial cells (21). The hierarchy of ATP-consuming reactions in the proximal tubule, with $\mathrm{Na}, \mathrm{K}-\mathrm{ATPase}$ apparently at the top, is important to consider $(58,59)$. Therefore, under hypoxic conditions, metabolic indicators could be generated without compromising tubular reabsorptive function.

What about the "gain" that amplifies the hypoxic signal? In the case of erythropoietin production, the gain could be represented by an increase in the number of hormone-producing cells as the severity of hypoxia increases. Determining the specific relationships between the degree of hypoxia, the level of erythropoietin mRNA in a given cell, and the number of hormoneproducing cells provides a thrilling task for future research, not only with specific regard to the regulation of hypoxia-induced erythropoietin production, but also for questions related to the general laws of signal recognition and signal processing.

\section{ACKNOWLEDGMENTS}

We are gratcful to Kai-Uwe Eckardt, Hartmut Osswald, Ulrich Pohl, and Hans-Joachim Schurek for many helpful discussions. We also express our 
thanks to Olga Stoupa for her most diligent secretarial help. The authors' research was partly supported by the Swiss National Science Foundation, the Roche Research Foundation, and the Hartmann Müller Stiftung für medizinische Forschung.

\section{Literature Cited}

1. Aperia, A. C., Liebow, A. A., Roberts, L. E. 1968. Renal Adaptation to Anemia. Circ. Res. 22:489-500

2. Aukland, K., Krog, J. 1960. Renal oxygen tension. Nature 188:671

3. Aw, T. Y., Jones, D. P. 1985. ATP concentration gradients in cytosol of liver cells during hypoxia. Am. J. Physiol. 249:C385-92

4. Bagnasco, S., Good, D., Balaban, R., Burg, M. 1985. Lactate production in isolated segments of the rat nephron. Am. J. Physiol. 248:F522-26

5. Bauer, C. 1988. Metabolic events that may activate erythropoietin production in the hypoxic kidney. In Oxygen Sensing in Tissues, ed. H. Acker, pp. 93101. Berlin; Springer-Verlag

6. Baumgärtl, H., Leichtweiss, H. P., Lübbers, W. W., Weiss, C., Huland, H. 1972. The oxygen supply of the dog kidney: measurements of intrarenal $\mathrm{pO}_{2}$. Microvasc. Res. 4:247-57

7. Behm, R., Gerber, B., Griffel, D., Spee, B., Zingler, C. 1987. Comparison of the response of renal sodium excretion to almitrine and hypoxia in conscious normotensive and spontaneously hypertensive rats. Biomed. Biochim. Acta 46:999-1004

8. Beru, N., McDonald, J., Lacombe, C., Goldwasser, E. 1986. Expression of the erythropoietin gene. Mol. Cell. Biol. 6:2571-75

9. Beynon, G. W., Balfour, W. E. 1973. The carotid body and erythropoiesis in the rat. Nature (New Biol.) 243:6162

10. Bondurant, M. C., Koury, M. J. 1986. Anemia induces accumulation of erythropoietin mRNA in the kidney and liver. Mol. Cell. Biol. 6:2731-33

11. Brezis, M., Rosen, S., Silvo, P., Epstein, F. H. 1984. Selective vulnerability of the medullary thick ascending limb to anoxia in the the isolated perfused rat kidney. J. Clin. Invest. 73:182-90

12. Busse, R., Förstermann, U., Matsuda, H., Pohl, U. 1984. The role of prostaglandins in the endothelium-mediated vasodilatory response to hypoxia. Pflügers Arch. 401:77-83

13. Chamberlain, M. E., Mandel, L. J. 1987. $\mathrm{Na}^{+}-\mathrm{K}^{+}$-ATPase activity in

medullary thick ascending limb during short-term anoxia. Am. J. Physiol. 252:F838-43

14. Cobum, R. F., 1988. ATP-sensing reactions and oxygen chemoreception. In Receptors and Reflexes During Breathing, ed. S. Lahiri, New York: Oxford Univ. Press

15. Cook, D. L., Hales, N. 1984. Intracellular ATP directly blocks $\mathrm{K}^{+}$channels in pancreatic B-cells. Nature 311:271-73

16. Deetjen, P., Kramer, K. 1961. Die Abhängigkeit des $\mathrm{O}_{2}$-Verbrauchs der Nicre von dcr Na-Rückresorption. Pflügers Arch. 273:636-50

17. Dume, T., Koch, K. M., Karuse, H. H., Ochwadt, B. 1966. Kritischer venöser Sauerstoffdruck an der erythrocytenfrei perfundierten isolierten Rattenniere. Pflügers Arch. 290:89-100

18. Erecinska, M., Wilson, D. F. 1982. Regulation of cellular energy metabolism. J. Membr. Biol. 70:1-14

19. Erslev, A. J., Caro, J., Miller, O., Silver, R. 1980. Plasma erythropoietin in health and disease. Ann. Clin. Lab. Sci. 10:250-57

20. Fisher, J. W., McGonigle, R., Beckman, B. 1986. Control mechanisms in kidney erythropoietin production. In Kidney Hormones, ed. J. W. Fisher, 3:463-74. London: Academic

21. Gordon, J. L. 1986. Extracellular ATP: effects, sources and fate. Biochem. J. 233:309-19

22. Grupp, I., Grupp, G., Holmes, J. C. Fowler, N. O. 1972. Regional blood flow in anemia. J. Appl. Physiol. $33: 456-61$

22a. Hall, J. E., Granger, J. P. 1986. Renal hemodynamics and arterial pressure during chronic intrarenal adenosine infusion in conscious dogs. Am. J. Physiol. 250:F32-F39

23. Honig, A. 1983. Role of the arterial chemoreceptors in the reflex control of renal function and body fluid volumes in acute arterial hypoxia. In Physiology of the Peripheral Arterial Chemoreceptors, ed. H. Ackcr, R. G. O'Regan, pp. 395429, Amsterdam: Elsevier.

24. Honig, A., Wedler, B., Zingler, C., Ledderhos, C., Schmidt, M. 1985. Kid- 
ney function during arterial chemoreceptor stimulation. III. Long-lasting inhibition of renal tubular sodium reabsorption due to pharmacological stimulation of the peripheral arterial chemoreceptors with almitrine bismesylate. Biomed. Biochim. Acta 44:1659-72

25. Jacobs, K., Shoemaker, C., Rudersdorf, R., Neill, S., Kaufmann, J., et al. 1985. Isolation and characterization of genomic and $\mathrm{cDN} \Lambda$ clones of human erythropoietin. Nature 313:806-10

26. Jacobson, L. O., Goldwasser, E., Fried, W., Plzak, L. 1957. Role of the kidney in erythropoiesis. Nature 179:633-34

27. Jelkmann, W. 1986. Renal erythropoietin: properties and production. Rev. Physiol. Biochem. Pharmacol. 104: 140-215

28. Jones, D. P. 1986. Renal metabolism during normoxia, hypoxia and ischemic injury. Annu. Rev. Physiol. 43:33-50

29. Kashiwagura, T., Wilson, D. F., Erecinska, M. 1984. Oxyyen dependence of cellular metabolism: the effect of $\mathrm{O}_{2}$ tension on gluconeogenesis and urea synthesis in isolated rat hepatocytes. $J$. Cell. Physiol. 120:13-18

30. Kiil, F., Aukland, K., Refsum, H. E. 1961. Renal sodium transport and oxygen consumption. Am. J. Physiol. 201:511-16

31. Koury, S. T., Bondurant, M. C., Koury, M. J. 1988. Localization of erythropoietin synthesizing cells in murine kidney by in situ hybridization. Blood 71:524-27

32. Kriz, W., Kaissling, B. 1985. Structural organisation of the mammalian kidney. In The Kidney: Physiology and Pathophysiology, ed. D. W. Seldin, G. Giebisch, 1:265-306. New York: Raven

32a. Kurtz, A., Eckardt, K.-U., Tannahill, L., Bauer, C. 1988. Regulation of erythropoietin production. Contrib. Nephrol. 66:1-16

33. Kurtz, A., Jelkmann, W., Pfeilschifter, J., Bauer, C. 1985. Role of prostaglandins in hypoxia-stimulated erythropoietin production. Am. J. Physiol. 249:C38

34. Kurtz, A., Pfeilschifter, J., Brown, C. D. A., Bauer, C. 1986. NaCl transport stimulates prostaglandin release in cultured renal epithelial (MDCK) cells. Am. J. Physiol. 250:C676-81

35. Kurtz, A., Pfeilschifter, J., Malmström, K., Woodson, R. D., Bauer, C. 1987. Mechanism of $\mathrm{NaCl}$ transport-stimulated prostaglandin formation in MDCK cells. Am. J. Physiol. 252:C307-14

36. Deleted in press

37. Lacombe, C., Da Silva, J. L., Bruneval,
P., Fournier, J. G., Wendling, F., et al. 1988. Peritubular cells are the site of erythropoietin synthesis in the murine hypoxic kidney. J. Clin. Invest. 81:62023

38. Lassen, N. A., Munck, O., Thaysen, J. H. 1961. Oxygen consumption and sodium reabsorption in the kidney. Acta Physiol. Scand. 51:371-84

39. Ledderhos, C., Quies, W., Schuster, R., Peters, R. 1987. Renal hemodynamics and excretory function of healthy young men during stimulation of their peripheral arterial chemoreceptors by almitrine bismesylate. Biomed. Biochim. Acta 12:1035-42

40. Leichtweiss, H. P., Lübbers, D. W., Weiss, C., Baumgärtl, H., Reschke, W. 1969. The oxygen supply of the rat kidney. Measurements of intrarenal $\mathrm{pO}_{2}$. Pflügers Arch. 309:328-49

41. Levy, M. N., Imperial, E. S. 1961. Oxygen shunting in renal cortical and medullary capillaries. Am. J. Physiol. 200:159-62

42. Lin, F. K., Suggs, S., Lin, C. H., Browne, J., Smalling, R., et al. 1985. Cloning and expression of the human erythropoietin gene. Proc. Natl. Acad. Sci. USA 82:7580-84

43. Lundberg, G. A., Jergil, B., Sunder, R. 1985. Subcellular localization and enzymatic properties of rat liver phosphatidylinositol-4-phosphate kinase. Biochim. Biophys. Acta 846:379-87

44. Mandel, L. J., Balaban, R. S. 1981. Stoichiometry and coupling of active transport to oxidative metabolism in epithelial tissues. Am. J. Physiol. 240: F357-71

45. McDonald, J. D., Lin, F.-K., Goldwasser E. 1986. Cloning, sequencing, and evolutionary analysis of the mouse erythropoietin gene. Mol. Cell. Biol. 6:842-48

46. Miyake, T., Kung, C. H. K., Goldwasser, E. 1977. Purification of human erythropoietin. J. Biol. Chem. 252: 5558-64

47. Nelson, W. J., Veshnak, P. J. 1987. Ankyrin binding to $\left(\mathrm{Na}^{+}-\mathrm{K}^{+}\right)$ATPase and implications for the organisation of membrane domains in polarized cells. Nature 328:533-36

48. Noma, A. 1985. ATP-regulated single K channels in cardiac muscle. Nature 305:147-48

49. Osswald, H. 1983. Adenosine and renal function. In Regulatory Function of Adenosine, ed. R. M. Beme, T. W. Roll, R. Rubio, pp. 399-415. London: Nijhof

49a. Paul, P., Rothmann, S. A., Meagher, 
R. C. 1988. Modulation of erythropoietin production by adenosine. J. Lab. Clin. Med. 112:168-73

50. Paulo, L. G., Fink, G. D., Roh, B. L., Fisher, J. W. 1973. Influence of carotid body ablation on erythropoietin production in rabbits. Am. J. Physiol. 224:44244

51. Powell, J. S., Berkner, K. L., Lebo, R.

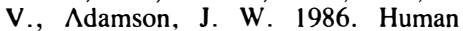
erythropoietin gene: High level expression in stably transfected mammalian cells and chromosome localization. Proc. Natl. Acad. Sci. USA 83:6465-69

52. Sasaki, H., Bothner, B., Dell, A., Fukuda, M. 1987. Carbohydrate structure of erythropoietin expressed in Chinese hamster ovary cells by a human erythropoietin cDNA. J. Biol. Chem. 262:12059-76

53. Schurek, H. J. 1988. Die Nierenmarkhypoxie: Ein Schlüssel zum Verständnis des akuten Nierenversagens? Klin. Wochenschr. 66:828-35

54. Schurek, H. J., Kriz, W. 1985. Morphological and functional evidence for oxygen deficiency in the isolated perfused rat kidney. Lab. Invest. 53:145-55

55. Schuster, S. J., Wilson, J. H., Erslev, A. J., Caro, J. 1987. Physiologic regulation and tissue localization of renal erythropoietin messenger RNA. Blood 70:316-18

56. Selkurt, E. E. 1953. Influence of hypoxia on renal circulation and on excretion of electrolytes and water. Am. J. Physi. ol. 172:700-8

57. Smith, H. 1951. The Kidney. Structure and Function in Health and Disease, pp.
10-14. New York: Oxford Univ. Press

58. Soltoff, S. P. 1986. $\Lambda$ TP and the regulation of renal cell function. Annu. Rev. Physiol. 48:9-31

59. Soltoff, S. P., Mandel, L. J. 1984. Active ion transport in the renal proximal tubule. III. The ATP dependence of the Na-Pump. J. Gen. Physiol. 84:64362

60. Thurau, K. 1961. Renal Na reabsorption and $\mathrm{O}_{2}$ uptakc in dogs during hypoxia and hydrochlorothiazide infusion. Proc. Soc. Exp. Biol. Med. 106:714-17

60a. Ueno, M., Brookins, J., Beckman, B., Fisher, J. W. 1988. $A_{1}$ and $A_{2}$ adenosine receptor regulation of erythropoietin production. Life Sci. 43:229-37

61. Walker, B. R. 1982. Diuretic response to acute hypoxia in the conscious dog. Amer. J. Physiol. 243:F440-46

62. Walker, L. A., Frölich, J. C. 1987. Renal prostaglandins and leukotrienes. Rev. Physiol. Biochem. Pharmacol. 107:2-72

63. Weismann, D. N. 1981. Altered renal hemodynamic and urinary prostaglandin response to acute hypoxemia after inhibition of prostaglandin synthesis in the anesthetized dog. Circ. Res. 48:63240

64. Wilson, D. F., Erecinska, M. 1985. Effect of oxygen concentration on cellular metabolism. Chest 885:2295-2325

65. Wilson, D. F., Owen, C. S., Erecinska, M. 1979. Quantitative dependence of mitochondrial oxidative phosphorylation on oxygen concentration: A mathematical model. Arch. Biochem. Biophys. 195:494-504 